\title{
An Analysis of the English Language Needs of Customer Contact and Secretarial Operation Coordination Trainees: Some Selected Technical and Vocational Colleges in Ethiopia
}

\author{
Sualih Mussa \\ Debre Markos University, Ethiopia \\ Yitayal Wondie \\ Bonga University, Ethiopia
}

\begin{abstract}
This study is mainly conducted to find out the English language needs of Customer Contact and Secretarial Operation Coordination Level IV trainees. To achieve this objective, purposive sampling technique was used to select content area teachers while comprehensive sampling technique was used to include trainees and English language teachers. A survey research was the design of this study. To this end, questionnaire and interview were employed to collect data. Both quantitative and qualitative methods of data analysis were used in the study. The findings of the study showed that writing, speaking, reading and listening skills are prioritized by trainees according to their order. In the area of micro skills, listening to lectures to take notes and listening to class discussions were showed as highly needed micro-skills. With regard to speaking activities, asking and answering questions and participating in whole class discussion were highly needed speaking micro-skills. Reading reference books and reading lecture notes, writing different project works like term papers, assignments and sample personal and business letters were identified as the most important speaking and writing micro-skills. Vocabulary was found more important than grammar. Most trainees reported that they find asking and answering questions and writing different project works like term papers and assignments, sample personal and business letters difficult. The reason for this might be because the courses offered are inefficient to help them develop these skills. Disparity was also found between their language problems and the courses they take. Finally, based on these findings, recommendations were also forwarded.
\end{abstract}

Index Terms —English language needs, macro- and micro-skills, reading, writing, speaking, listening

\section{INTRODUCTION}

Biniam et al (2015) state, "English for Specific Purpose (ESP) has witnessed substantial growth over the past five decades" which shows its long history all over the world (p.1). The reason for this considerable development as Serkan (2003) states is the effort and motivations of people to learn English language for their either professional or educational purposes which create a great opportunity for educational institutions like universities and vocational colleges to understand the concept of specialization and professionalism. According to Hutchinson and Waters (1987), Kumar (2020) and Dudley-Evans \& St. John, (1998), the need to train students in different vocations and subject specific fields pushed ESP to the fore front.

Similarly in Ethiopia, there are necessities, practices and developments of ESP in teaching English as a foreign language because of the expansion of field specific Technical and Vocational Education and Training (TVET) colleges. Regarding this, Biniam et al (2015), Tadele and Haileleul (2015) suggest currently ESP is one of the most important areas of English language teaching in Ethiopia. But nowadays, ESP is not given enough emphasis for all programs in Ethiopian TVET institutions. As Ahmed et al (2017) indicate, in the current Ethiopian vocational trainings where the trainees are expected to be skillful and knowledgeable in their specific field of study, English language skills based on trainees needs are given little emphasis contrary to what is expected to be achieved by meticulous trainees. That is, English language course materials are not designed to meet the trainees' particular English language needs. Due to this absence of any particular English language course designed, a gap is created between trainees' English language needs and English language courses being offered to them. This negatively affects trainees' capabilities to learn based on their needs and waste time on courses that do not meet their needs. Having observed the adverse effect of this gap, the researchers argue that learning English language can be effective when the actual English language needs of trainees are analyzed.

\section{A. Statements of the Problem}

As it is indicated earlier, by using English language as a medium of instruction, Ethiopia is running TVET programs 
in both private and governmental institutions to produce competent and skilled man power. Newman and Dima Technology Colleges are among Ethiopian TVET intuitions found in Debre Markos Town. Even though, English language is a medium of instruction and given as a course to such colleges, the courses are not designed based on the trainees' needs. Specifically, based on the researchers' experience and observation, the problem is serious in Newman and Dima Technology Colleges because based on the direction given from Ethiopian TVET model curriculum, these colleges are using commonly given English language courses for all trainees without considering trainees' particular English language needs. That is, English language courses are not designed properly based on trainees' particular needs. This makes the course material incapable to meet trainees' English language needs. As a result, currently enrolled trainees have difficulties to learn English and other courses. Particularly, trainees have difficulties to make oral presentation and writing different documents like memorandum, minutes and different types of letters.

In spite of all these problems, as far as the researchers' knowledge is concerned, there is no special attention on the side of TVET syllabus designers to prepare appropriate English language course to meet the needs of the trainees. This problem was observed by one of the researchers in different organizations and TVET colleges of Debre Markos town when he was working as an English teacher, cooperative training facilitator and dean. Thus, the present study tried to analyze the English language needs of Customer Contact and Secretarial Operation Coordination Level IV Trainees in the two colleges found in Debre Markos town.

\section{B. Objectives of the Study}

This study has both general and specific objectives.

\section{General Objective}

The general objective of this research was to analyze the English language needs of Customer Contact and Secretarial Operation Coordination Level IV trainees of Newman and Dima Technology colleges.

\section{Specific Objectives}

In addition to the above general objective, this study specifically attempts to:

1. identify the specific English language micro-skills Customer Contact and Secretarial Operation Coordination Level IV trainees need to have

2. identify trainees' current difficulties in learning the English language skills

3. investigate trainees' attitude towards learning English language

\section{Research Questions}

On the bases of the above general and specific objectives, an attempt was made to answer the following research questions:

1. Which English language skills do Customer Contact and Secretarial Operation Coordination Level IV trainees need to have?

2. What English language skills difficulties do Customer Contact and Secretarial Operation Coordination Level IV trainees have?

3. What is trainees' attitude towards learning English language?

\section{RESEARCH METHODOLOGY}

\section{A. Research Design}

The researchers used a survey research design for this study. This study adopted a mixed-methods research. The researchers collected and analyzed quantitative data that were obtained from the questionnaire and qualitative data obtained from interview.

\section{B. Population of the Study}

There were three groups of participants in this study: all Customer Contact and Secretarial Operation Coordination level IV trainees of 2019 academic year, content area teachers, and English language teachers.

\section{Samples and Sampling Techniques}

Colleges were selected by using purposive sampling techniques for this study. Since they are easy to manage, the researchers used all English language teachers and all the seventy eight (78) trainees enrolled in the 2019 academic year by using comprehensive sampling technique. Similarly, based on seniority, the researchers selected 2 content area teachers from each college.

\section{Data gathering Instruments}

Questionnaire and semi-structured interview have been used as a data gathering too.

\section{Questionnaire}

A questionnaire was the main data gathering instrument in this research because as Krathwohl (1998) notes the advantages of using questionnaires is to collect data quickly and economically from a large sample. Thus, questionnaire was used in this study in order to get the information that cannot be obtained through direct observation and interview. Contents of the item of the questionnaire mainly focused on identifying the specific English language skills needed by 
trainees, the problems trainees faced and the attitudes of trainees towards learning English language in their academic study. During designing the questionnaire, effort has been made to make the questionnaire as comprehensive and representative as possible.

\section{Interview}

In this study, semi-structured interview was used to get first hand and genuine information from the respondents. The researchers adapted semi-structured interview questions for English language and content area teachers. Contents of the items of the interview questions mainly focused on identifying English language skills and activities trainees need and the problems they face in learning the language.

\section{Validity and Reliability of Data Gathering Instruments}

To ascertain the validity and reliability of the questionnaire, before the researchers distributed questionnaires for actual data collection, they piloted on the trainees that were found at the similar level with selected informants or target respondents. Furthermore, in order to insure the contents and face validity of the questionnaire, the researchers showed the questionnaire to different English language instructors and their close friends who had some background knowledge about the issue. Besides, the researchers used Cronbach Alpha (SPSS-Version 20.00 to check the internal consistency of the questionnaire. Accordingly, 0.83 value of $\mathrm{r}$ shows good reliability. Additionally, in terms of interview questions, similar explanation, extension question and equal waiting time have been given for all participants.

\section{Data Collection Procedure}

Questionnaire was employed before using interview to triangulate data.

\section{Methods of Data Analysis}

In this study, both quantitative and qualitative methods of data analysis were used. To analyze quantitative data collected from questionnaires, the researchers used SPSS version 20.0. In order to identify trainees' English language needs, difficulties and attitudes toward the English language learning. The following scale was used to analyze the means of the questionnaire: $<1.49=$ not (never) needed, 1.5-2.49=rarely needed, 2.5-3.49 = sometimes needed, 3.5-4.49 $=$ frequently needed and $>4.5=$ very greatly (very frequently) needed. The data gathered through interview was analyzed qualitatively.

\section{RESULTS AND DISCUSSION}

\section{A. Trainees' Needs of Macro Skills}

The first research question was formulated to elicit the trainees' needs of English language macro- skills. The following table gives this.

TABLE 1

TRAINEES’ NEEDS OF ENGLISH LANGUAGE MACRO-SKILLS

\begin{tabular}{|c|c|c|c|c|c|c|c|c|c|c|c|c|}
\hline \multirow[t]{2}{*}{ Macro-Skills } & \multicolumn{2}{|c|}{ VFN } & \multicolumn{2}{|l|}{$\mathrm{FN}$} & \multicolumn{2}{|l|}{$\mathrm{SN}$} & \multicolumn{2}{|c|}{$\mathrm{RN}$} & \multicolumn{2}{|c|}{$\mathrm{NN}$} & \multirow[b]{2}{*}{ Mean } & \multirow[b]{2}{*}{ Ranks } \\
\hline & $\mathrm{F}$ & $\%$ & $\mathrm{~F}$ & $\%$ & $\mathrm{~F}$ & $\%$ & $\mathrm{~F}$ & $\%$ & $\mathrm{f}$ & $\%$ & & \\
\hline 1.Listening & 27 & 36.5 & 21 & 28 & 16 & 21.62 & 10 & 13.51 & 0 & 0 & 3.88 & 4 \\
\hline 2.Speaking & 43 & 58 & 13 & 17.56 & 9 & 12.16 & 6 & 8.10 & 3 & 4.05 & 4.18 & 2 \\
\hline 3.Reading & 39 & 52 & 15 & 20.27 & 12 & 16.21 & 8 & 10.81 & 0 & 0 & 4.15 & 3 \\
\hline 4.Writing & 55 & 74 & 9 & 12 & 7 & 9.46 & 3 & 4.05 & 0 & 0 & 4.57 & 1 \\
\hline Grand mean & & & & & & & & & & & 4.20 & \\
\hline
\end{tabular}

As indicated from table 1 above, the mean score of each macro-skill was calculated. As the results show, almost all respondents prioritized writing skill for their academic purpose with the mean value 4.57. Next to writing skill, speaking skill was the second needed skill with the mean value of 4.18. According to their mean score, reading skill $(\mathrm{M}=4.15)$ and listening skill $(\mathrm{M}=3.88)$ were ranked as the third and fourth prioritized skills respectively. According to the information in the above table, trainees confirmed that all four English language macro-skills are frequently needed for their academic study because the grand mean is 4.20. Similarly, the results of teachers' interviews were concurrent to the results obtained from trainees' questionnaire.

\section{B. Trainees' Needs of Micro Skills}

Trainees were asked about their micro-skill needs under each macro skill, shown in following section. 
TABLE 2

TRAINEES' NEEDS OF LISTENING MICRO-SKILLS

\begin{tabular}{|c|c|c|c|c|c|c|c|c|c|c|c|c|}
\hline \multirow[t]{2}{*}{ Micro-skills of listening } & \multicolumn{2}{|c|}{ VFN } & \multicolumn{2}{|l|}{ FN } & \multicolumn{2}{|l|}{ SN } & \multicolumn{2}{|c|}{$\mathrm{RN}$} & \multicolumn{2}{|c|}{ NN } & \multirow[t]{2}{*}{ Mean } & \multirow[t]{2}{*}{ Ranks } \\
\hline & $\mathrm{F}$ & $\%$ & $\mathrm{~F}$ & $\%$ & $\mathrm{~F}$ & $\%$ & f & $\%$ & $\mathrm{~F}$ & $\%$ & & \\
\hline Listening the content of in-class activities & 38 & 51.2 & 21 & 28.2 & 9 & 12.2 & 2 & 2.7 & 4 & 5.4 & 4.18 & 3 \\
\hline Listening to instructors' questions & 21 & 28.2 & 20 & 27 & 19 & 25.7 & 5 & 6.8 & 9 & 12.2 & 3.53 & 6 \\
\hline Listening to class discussions & 44 & 59.5 & 19 & 25.7 & 3 & 4.1 & 7 & 9.5 & 1 & 1.4 & 4.32 & 2 \\
\hline Listening lectures to take notes & 52 & 70.3 & 9 & 12.2 & 7 & 9.5 & 6 & 8 & 0 & 0 & 4.45 & 1 \\
\hline Listening students' oral presentation & 31 & 41.9 & 23 & 31.1 & 20 & 27 & 0 & 0 & 0 & 0 & 4.15 & 4 \\
\hline Listening lectures' oral instructions & 25 & 33.8 & 11 & 14.9 & 31 & 41.9 & 7 & 9.5 & 0 & 0 & 3.73 & 5 \\
\hline Grand mean & & & & & & & & & & & 3.70 & \\
\hline
\end{tabular}

NB: VFN= Very Frequently Needed, FN= Frequently Needed, SN= Sometimes Needed, RN= rarely needed and NN= Never Needed

As depicted on the above table, listening to lectures to take notes is the first frequently needed listening micro-skill with mean score of 4.45 , followed by listening to class discussions $(M=4.32)$. Listening to the content of in-class activities and listening to students' oral presentation were the third and fourth needed activities with mean score of 4.18 and 4.15 respectively. Next to these, listening to lecturers' oral instructions and listening to instructors' questions are the fifth and sixth listening activities with mean score of 3.73 and 3.53 respectively. As indicated in the above table, the grand mean score of the above listening activities inclines to the scale 'frequently needed'. In support of this finding, most of English language and content area teachers in their response to the interview forwarded similar results.

TABLE 3

TRAINEES’ NEEDS OF SPEAKING MICRO-SKILLS

\begin{tabular}{|c|c|c|c|c|c|c|c|c|c|c|c|c|}
\hline \multirow[t]{2}{*}{ Speaking micro-skills } & \multicolumn{2}{|c|}{ VFN } & \multicolumn{2}{|c|}{ FN } & \multicolumn{2}{|l|}{ SN } & \multicolumn{2}{|c|}{$\mathrm{RN}$} & \multicolumn{2}{|c|}{ NN } & \multirow[t]{2}{*}{ Mean } & \multirow[t]{2}{*}{ Rank } \\
\hline & $\mathrm{F}$ & $\%$ & $\mathrm{~F}$ & $\%$ & $\mathrm{~F}$ & $\%$ & $\mathrm{~F}$ & $\%$ & $\mathrm{~F}$ & $\%$ & & \\
\hline Asking and answering questions & 56 & 75.7 & 6 & 8 & 6 & 8 & 4 & 5.4 & 2 & 2.7 & 4.49 & 1 \\
\hline Participating in whole class discussion & 40 & 54.1 & 9 & 12.2 & 10 & 13.5 & 15 & 20.3 & 0 & 0 & 4.00 & 2 \\
\hline $\begin{array}{l}\text { Making Conversations with classmates and } \\
\text { instructors }\end{array}$ & 39 & 52.7 & 10 & 13.5 & 8 & 10.8 & 16 & 21.6 & 1 & 1.4 & 3.95 & 3 \\
\hline $\begin{array}{l}\text { Asking and answering questions orally in job- } \\
\text { related trainings }\end{array}$ & 35 & 47.3 & 14 & 18.9 & 11 & 14.9 & 8 & 10.8 & 6 & 8 & 3.86 & 4 \\
\hline Presenting assignments and project works & 28 & 37.8 & 17 & 23 & 12 & 16 & 16 & 21.6 & 1 & 1.4 & 3.74 & 5 \\
\hline
\end{tabular}

NB: VFN= Very Frequently Needed, FN= Frequently Needed, SN= Sometimes Needed, RN= rarely needed and NN= Never Needed

According to the table above, asking and answering questions (in classroom, lab and fields) was the first prioritized micro-skill with mean value of 4.49. Trainees rated participating in whole class discussion (in classroom, field practice) second with mean score of 4.00 , followed by making conversations with classmates and instructors with mean value of 3.96. Asking and answering questions orally in job related trainings and presenting assignments were the fourth and fifth needed micro-skills of speaking with mean value of 3.86 and 3.74 respectively. The data obtained from the majority of English language and content teachers' interview ascertains the finding obtained from trainees.

TABLE 4

TRAINEES' NEEDS OF READING MICRO-SKILLS

\begin{tabular}{|c|c|c|c|c|c|c|c|c|c|c|c|c|}
\hline \multirow[t]{2}{*}{ Reading activities /sub-skill } & \multicolumn{2}{|c|}{ VFN } & \multicolumn{2}{|l|}{ FN } & \multicolumn{2}{|c|}{ SN } & \multicolumn{2}{|c|}{$\mathrm{RN}$} & \multicolumn{2}{|c|}{ NN } & \multirow[t]{2}{*}{ Mean } & \multirow[t]{2}{*}{ Rank } \\
\hline & $\mathrm{F}$ & $\%$ & $\mathrm{~F}$ & $\%$ & $\mathrm{~F}$ & $\%$ & $\mathrm{~F}$ & $\%$ & $\mathrm{~F}$ & $\%$ & & \\
\hline $\begin{array}{l}\text { Reading reference books } \\
\text { secretaries) }\end{array}$ & 50 & 67.6 & 11 & 14.9 & 8 & 10.8 & 5 & 6.8 & 0 & 0 & 4.43 & 1 \\
\hline $\begin{array}{l}\text { Reading handouts/ materials/ relating to your } \\
\text { courses }\end{array}$ & 48 & 64.9 & 14 & 18.9 & 6 & 8 & 6 & 8 & 0 & 0 & 4.41 & 3 \\
\hline Reading lecture notes & 49 & 66 & 12 & 16 & 8 & 10.8 & 5 & 6.8 & 0 & 0 & 4.42 & 2 \\
\hline Reading test and exam questions & 41 & 55 & 22 & 29.7 & 10 & 13.5 & 1 & 1.4 & 0 & 0 & 4.39 & 4 \\
\hline Reading secretarial and customer relation rules & 40 & 54.1 & 15 & 20.3 & 10 & 13.5 & 8 & 10.8 & 1 & 1.4 & 4.15 & 5 \\
\hline Grand mean & & & & & & & & & & & 3.64 & \\
\hline
\end{tabular}

NB: VFN= Very Frequently Needed, FN= Frequently Needed, SN= Sometimes Needed, RN= rarely needed and NN= Never Needed

The data gained from trainees' questionnaire in table 4 above revealed that reading reference books (English for secretary, customer relationship and effective secretary) is indicated the most important reading activity for trainees' academic achievement with mean score of 4.43. Similarly, reading lecture notes and reading handouts (course materials) are the second and third frequently needed reading activities with mean values of 4.42 and 4.41 respectively. While reading test and exam questions with mean value of 4.39 is the fourth needed sub-skill, reading secretarial and customer relation rules $(M=4.15)$ stood last. Similarly, supporting this finding most English and content area teachers also articulated reading reference books (English for secretary and customer relationship as well as effective secretary) were the most important reading activities for trainees' academic achievement. 
TABLE 5

TRAINEES' NEEDS OF WRITING MICRO-SKILLS

\begin{tabular}{|c|c|c|c|c|c|c|c|c|c|c|c|c|}
\hline \multirow{2}{*}{ writing sub-skill } & \multicolumn{2}{|c|}{ VFN } & \multicolumn{2}{|l|}{ FN } & \multicolumn{2}{|l|}{ SN } & \multicolumn{2}{|c|}{$\mathrm{RN}$} & \multicolumn{2}{|c|}{$\mathrm{NN}$} & \multirow{2}{*}{ Mean } & \multirow{2}{*}{ Rank } \\
\hline & $\mathrm{F}$ & $\%$ & $\mathrm{~F}$ & $\%$ & $\mathrm{~F}$ & $\%$ & $\mathrm{~F}$ & $\%$ & $\mathrm{~F}$ & $\%$ & & \\
\hline $\begin{array}{l}\text { Writing notes from lecture notes } \\
\text { (note taking) }\end{array}$ & 26 & 35 & 18 & 24 & 16 & 21.6 & 12 & 16 & 2 & 2.7 & 3.73 & 4 \\
\hline $\begin{array}{l}\text { Using correct punctuation and } \\
\text { spelling }\end{array}$ & 18 & 24 & 21 & 28.4 & 31 & 41.9 & 4 & 5 & 0 & 0 & 3.72 & 5 \\
\hline Writing lab and field reports & 41 & 55 & 12 & 16 & 10 & 13.5 & 9 & 12.2 & 2 & 2.7 & 4.09 & 3 \\
\hline $\begin{array}{l}\text { Writing different project works (term } \\
\text { papers and assignments }\end{array}$ & 59 & 79.7 & 7 & 9.5 & 4 & 5 & 3 & 4.1 & 1 & 1.4 & 4.62 & 1 \\
\hline $\begin{array}{l}\text { Writing sample personal and } \\
\text { business letters }\end{array}$ & 57 & 77 & 8 & 10.8 & 3 & 4.1 & 3 & 4.1 & 3 & 4.1 & 4.53 & 2 \\
\hline Grand mean & & & & & & & & & & & 3.74 & \\
\hline
\end{tabular}

NB: VFN= Very Frequently Needed, FN= Frequently Needed, SN= Sometimes Needed, RN= rarely needed and NN= Never Needed

As the above table shows, trainees indicated that the most frequently needed sub-skill is writing different project works (term papers \& assignments) with mean score of 4.62, followed by writing personal and business letters $(\mathrm{M}=4.53)$. These means fall with the scale of 'very frequently needed'. Writing lab and fie ld reports, writing notes from lecture notes, using correct punctuation and spelling are sometimes needed activities with mean score of 4.09, 3.73 and 3.72 respectively. As it is clearly shown, these score are inclined to the scale 'frequently needed'. The data gained from content area teachers' interview was concurrent to the data obtained from trainees' questionnaire.

TABLE 6

TRAINEES RESPONSES ON THE NEEDS OF ASPECTS OF LANGUAGE (GRAMMAR AND VOCABULARY)

\begin{tabular}{|c|c|c|c|c|c|c|c|c|c|c|c|c|}
\hline \multirow{2}{*}{ General statement } & \multicolumn{2}{|l|}{ SA } & \multicolumn{2}{|c|}{ A } & \multicolumn{2}{|c|}{ UD } & \multicolumn{2}{|l|}{$\mathrm{D}$} & \multicolumn{2}{|c|}{ SD } & \multirow[b]{2}{*}{ Mean } & \multirow[b]{2}{*}{ Rank } \\
\hline & $\mathrm{F}$ & $\%$ & $\mathrm{~F}$ & $\%$ & f & $\%$ & $\mathrm{f}$ & $\%$ & $\mathrm{~F}$ & $\%$ & & \\
\hline $\begin{array}{l}\text { Having good English language knowledge in grammar is } \\
\text { important for my academic study. }\end{array}$ & 24 & 32 & 46 & 62.2 & 3 & 4.1 & 1 & 1.4 & 0 & 0 & 4.26 & 2 \\
\hline Having good knowledge in technical vocabularies & 41 & 55 & 32 & 43 & 1 & 1.4 & 0 & 0 & 0 & 0 & 4.54 & 1 \\
\hline
\end{tabular}

Keys: SA= Strongly Agree, A= Agree, UD= Undecided; D= Disagree and SD=Strongly Disagree,

As indicated in the above table, trainees were asked to what extent they agree to the idea that a good knowledge of grammar and technical vocabularies for their academic study are needed. As it is depicted clearly, both grammar knowledge and technical vocabularies are important for trainees' academic purpose. But, when we compare the two language areas, having a good knowledge in technical vocabulary items $(M=4.54)$ is more important than having good grammar $(\mathrm{M}=4.26)$.

\section{Trainees' Difficulty Levels of English Language Macro and Micro-skills}

TABLE 7

TRAINEES’ DIFFICULTY LEVEL OF ENGLISH LANGUAGE MACRO-SKILLS

\begin{tabular}{|c|c|c|c|c|c|c|c|c|c|c|c|c|}
\hline \multirow[t]{2}{*}{ Macro skills } & \multicolumn{2}{|c|}{ VMD } & \multicolumn{2}{|c|}{ MD } & \multicolumn{2}{|c|}{ SD } & \multicolumn{2}{|c|}{ LD } & \multicolumn{2}{|c|}{ ND } & \multirow[t]{2}{*}{ Mean } & \multirow[t]{2}{*}{ Rank } \\
\hline & $\mathrm{F}$ & $\%$ & $\mathrm{~F}$ & $\%$ & $\mathrm{~F}$ & $\%$ & $\mathrm{~F}$ & $\%$ & $\mathrm{f}$ & $\%$ & & \\
\hline Listening & 24 & 32 & 17 & 23 & 14 & 18.9 & 8 & 10.8 & 11 & 14.9 & 3.47 & 4 \\
\hline Speaking & 58 & 78.4 & 11 & 14.9 & 3 & 4.1 & 2 & 2.7 & 0 & 0 & 4.69 & 1 \\
\hline Reading & 41 & 55.4 & 18 & 24.3 & 5 & 6.8 & 4 & 5.4 & 6 & 8.1 & 4.14 & 3 \\
\hline Writing & 55 & 74 & 9 & 12.2 & 9 & 12.2 & 1 & 1.4 & 0 & 0 & 4.60 & 2 \\
\hline
\end{tabular}

NB: VMD= Very Much Difficult, MD= Much Difficult, $\mathrm{SD}=$ Somewhat Difficult, $\mathrm{LD}=$ Little Difficult and ND= Not Difficult.

As it is clearly indicated in the above table, speaking and writing skills with mean score of 4.69 and 4.60 respectively are very much difficult skills. These are followed by reading and listening skills with mean score of 4.14 and 3.49 respectively. Similarly, the data gained from both English language teachers' and content area teachers' interviews were concurrent to the findings obtained from trainees' questionnaire.

TABLE 8

TRAINEES’ DIFFICULTY LEVEL OF LISTENING MICRO-SKILLS

\begin{tabular}{|c|c|c|c|c|c|c|c|c|c|c|c|c|}
\hline \multirow[b]{2}{*}{ Listening micro-skills } & \multicolumn{2}{|c|}{ VMD } & \multicolumn{2}{|c|}{ MD } & \multicolumn{2}{|c|}{ SD } & \multicolumn{2}{|c|}{ LD } & \multicolumn{2}{|c|}{ ND } & \multirow[t]{2}{*}{ mean } & \multirow[t]{2}{*}{ Rank } \\
\hline & $\mathrm{F}$ & $\%$ & $\mathrm{~F}$ & $\%$ & $\mathrm{f}$ & $\%$ & $\mathrm{~F}$ & $\%$ & $\mathrm{~F}$ & $\%$ & & \\
\hline Listening the content of in-class activities & 46 & 62.2 & 11 & 14.9 & 5 & 6.8 & 8 & 10.8 & 4 & 5 & 4.18 & 2 \\
\hline Listening to instructors' questions & 33 & 44.6 & 19 & 25.7 & 15 & 20.3 & 5 & 6.8 & 2 & 2.7 & 4.03 & 3 \\
\hline Listening to class discussions & 18 & 24 & 24 & 32 & 16 & 21.6 & 8 & 10.8 & 8 & 10.8 & 3.49 & 5 \\
\hline $\begin{array}{l}\text { Listening lectures to take notes (in classroom \& } \\
\text { lab) }\end{array}$ & 52 & 70.3 & 11 & 14.9 & 6 & 8 & 2 & 2.7 & 3 & 4.1 & 4.45 & 1 \\
\hline Listening lectures' oral instructions & 34 & 45.9 & 15 & 20.3 & 13 & 17.6 & 10 & 13.5 & 2 & 2.7 & 3.93 & 4 \\
\hline
\end{tabular}

NB: VMD= Very Much Difficult, MD= Much Difficult, SD= Somewhat Difficult, LD= Little Difficult and ND= Not Difficult. 
As indicated in the above table, trainees reported their level of difficulties beginning from 'very much difficult up to not difficult. As clearly shown, listening to lectures to take notes (in classroom and lab) is the first difficult activity with mean score of 4.45 , followed by listening to the content of in-class activities with mean score of 4.18. Listening to instructors' questions, listening to lecturers' oral instructions and listening to class discussions are the $3^{\text {rd }}, 4^{\text {th }}$ and $5^{\text {th }}$ difficult listening activities with mean score of 4.03, 3.93 and 3.49. Supporting the above findings most English language and content area teachers' interview results confirmed that listening to lectures to take notes and listening to the contents of in-class activities were the most difficult listening activities in the classroom.

TABLE 9

TRAINEES’ DIFFICULTY LEVEL OF SPEAKING SUB-SKILLS

\begin{tabular}{|c|c|c|c|c|c|c|c|c|c|c|c|c|}
\hline \multirow[t]{2}{*}{ Speaking sub-skills } & \multicolumn{2}{|c|}{ VMD } & \multicolumn{2}{|c|}{ MD } & \multicolumn{2}{|c|}{ SD } & \multicolumn{2}{|c|}{ LD } & \multicolumn{2}{|c|}{ ND } & \multirow[b]{2}{*}{ Mean } & \multirow[b]{2}{*}{ Rank } \\
\hline & F & $\%$ & f & & $\mathrm{F}$ & & $\mathrm{F}$ & & F & & & \\
\hline $\begin{array}{l}\text { Presenting assignments and project } \\
\text { works }\end{array}$ & 63 & 85 & 6 & 8 & 5 & 6.8 & 0 & 0 & 0 & 0 & 4.78 & 1 \\
\hline Participating in whole class discussion & 51 & 68.9 & 9 & 12.2 & 7 & 9.5 & 5 & 6.8 & 2 & 2.7 & 4.38 & 5 \\
\hline $\begin{array}{l}\text { Making Conversations with classmates } \\
\text { and instructors }\end{array}$ & 62 & 83.8 & 6 & 8 & 4 & 5 & 1 & 1.4 & 1 & 1.4 & 4.72 & 3 \\
\hline $\begin{array}{l}\text { Asking and answering questions orally in } \\
\text { job-related }\end{array}$ & 61 & 82 & 9 & 12.2 & 4 & 5 & 0 & 0 & 0 & 0 & 4.77 & 2 \\
\hline Asking and answering questions & 57 & 77 & 6 & 8 & 5 & 6.8 & 4 & 5 & 2 & 2.7 & 4.51 & 4 \\
\hline
\end{tabular}

NB: VMD= Very Much Difficult, MD= Much Difficult, SD= Somewhat Difficult, LD= Little Difficult and ND= Not Difficult.

The information in table 9 above showed that the most difficult speaking sub-skill to trainees is presenting assignments and project works in the class with mean score of 4.78. Asking and answering questions orally in job related trainings $(M=4.77)$, making conversations with classmates and instructors $(M=4.72)$ and asking and answering questions (in classroom) $(M=4.51)$ are presented the $2^{\text {nd }}, 3 \mathrm{rd}$ and $4^{\text {th }}$ difficult speaking micro-skills for trainees'. Additionally, participating in whole class discussion (in classroom, field practice) is the $5^{\text {th }}$ difficult speaking sub-skill with mean score of 4.38. From the results shown in table 10, one can deduce that trainees have very great difficulties on speaking micro skills. The finding obtained from teachers' interview was parallel to this result.

TABLE 7

TRAINEES’ DIFFICULTY LEVELS OF READING SUB-SKILLS

\begin{tabular}{|c|c|c|c|c|c|c|c|c|c|c|c|c|}
\hline \multirow[t]{2}{*}{ Reading sub-skills } & \multicolumn{2}{|c|}{ VMD } & \multicolumn{2}{|c|}{ MD } & \multicolumn{2}{|l|}{ SD } & \multicolumn{2}{|c|}{ LD } & \multicolumn{2}{|c|}{ ND } & \multirow[t]{2}{*}{ Mean } & \multirow[t]{2}{*}{ Rank } \\
\hline & $\mathrm{F}$ & $\%$ & $\mathrm{~F}$ & $\%$ & $\mathrm{f}$ & $\%$ & $\mathrm{f}$ & $\%$ & $\mathrm{~F}$ & $\%$ & & \\
\hline Reading lecture notes & 16 & 21.6 & 31 & 41.9 & 16 & 21.6 & 8 & 10.8 & 3 & 4.1 & 3.66 & 5 \\
\hline Reading test and exam questions & 37 & 50 & 9 & 12.2 & 7 & 9.5 & 12 & 16 & 9 & 12.2 & 3.72 & 4 \\
\hline Reading technical secretarial manuals and guides & 60 & 81.1 & 5 & 6.8 & 3 & 4.1 & 4 & 5 & 2 & 2.7 & 4.58 & 1 \\
\hline Reading secretarial and customer relation rules & 39 & 52.7 & 13 & 17.6 & 5 & 6.8 & 11 & 14.9 & 6 & 8 & 3.92 & 3 \\
\hline Reading Rules of writing different types of letters & 49 & 66 & 10 & 13.5 & 5 & 6.8 & 8 & 10.8 & 2 & 2.7 & 4.30 & 2 \\
\hline
\end{tabular}

As indicated on the above table, trainees responded their level of difficulties beginning from very much difficult up to not difficult. As shown in the table, reading technical secretarial manuals and guides is the first difficult sub-skill for trainees $(M=4.58)$, followed by reading rules of writing different types of letters and reading secretarial and customer relation rules with mean score of 4.30 and 3.92 respectively. Reading test and exam questions and reading lecture notes are the next most difficult sub-skills with mean score of 3.72 and 3.66 respectively.

TABLE 11

TRAINEES’ DIFFICULTY LEVELS OF WRITING SUB-SKILLS

\begin{tabular}{|c|c|c|c|c|c|c|c|c|c|c|c|c|}
\hline \multirow[t]{2}{*}{ Writing Sub-Skill } & \multicolumn{2}{|c|}{ VMD } & \multicolumn{2}{|c|}{ MD } & \multicolumn{2}{|c|}{ SD } & \multicolumn{2}{|c|}{ LD } & \multicolumn{2}{|c|}{ ND } & \multirow[t]{2}{*}{ Mean } & \multirow[t]{2}{*}{ rank } \\
\hline & $\mathrm{F}$ & $\%$ & $\mathrm{~F}$ & $\%$ & $\mathrm{f}$ & $\%$ & $\mathrm{~F}$ & $\%$ & $\mathrm{~F}$ & $\%$ & & \\
\hline Expressing ideas appropriately & 58 & 78.4 & 7 & 9.5 & 5 & 6.8 & 3 & 4.1 & 1 & 1.4 & 4.59 & 2 \\
\hline Writing project works & 49 & 66 & 13 & 17.6 & 5 & 6.8 & 7 & 9.5 & 0 & 0 & 4.41 & 4 \\
\hline Writing lab and field reports & 55 & 74 & 9 & 12.2 & 6 & 8 & 4 & 5 & 0 & 0 & 4.55 & 3 \\
\hline Writing summaries & 48 & 64.9 & 11 & 14.9 & 8 & 10.8 & 6 & 8 & 1 & 1.4 & 4.34 & 5 \\
\hline Writing sample job-application letters\& CV & 54 & 73 & 15 & 20.3 & 3 & 4.1 & 2 & 2.7 & 0 & 0 & 4.64 & 1 \\
\hline
\end{tabular}

NB: VMD= Very Much Difficult, MD= Much Difficult, SD= Somewhat Difficult, LD= Little Difficult and ND= Not Difficult.

As it is depicted on the table above, trainees' writing sub-skill difficulties varied from 'very much difficult' to 'not difficult'. As the mean values of the trainees' response showed writing sample job-application letters and CV's, expressing ideas appropriately and writing lab and field reports (with mean value 4.64, 4.59 and 4.55) were very much difficult writing sub-skills. Additionally, writing project works/ term papers and writing summaries were indicated as much difficult activities with mean score 4.41and 4.34 respectively. From the result indicated, one can conclude that trainees had great difficulty on the above writing activities because most of the mean scores were above 3.5.

D. Trainees Attitudes towards Learning English Language 
TABLE 12

TRAINEES ATtITUDES TOWARDS LEARNING THE ENGLISH LANGUAGE

\begin{tabular}{|c|c|c|c|c|c|c|c|c|c|c|c|}
\hline \multirow[t]{2}{*}{ Trainees' attitude } & \multicolumn{2}{|l|}{ SA } & \multicolumn{2}{|l|}{ A } & \multicolumn{2}{|c|}{ UD } & \multicolumn{2}{|l|}{$\mathrm{D}$} & \multicolumn{2}{|c|}{ SD } & \multirow[t]{2}{*}{ Mean } \\
\hline & $\mathrm{F}$ & $\%$ & $\mathrm{~F}$ & $\%$ & $\mathrm{f}$ & $\%$ & $\mathrm{f}$ & $\%$ & $\mathrm{f}$ & $\%$ & \\
\hline Learning English is very important. & 60 & 81.1 & 8 & 10.8 & 5 & 6.8 & 1 & 1.4 & 0 & 0 & 4.72 \\
\hline I really like learning English. & 59 & 79.7 & 6 & 8 & 7 & 9.5 & 1 & 1.4 & 1 & 1.4 & 4.64 \\
\hline $\begin{array}{l}\text { English language is an important part of the TVET } \\
\text { program. }\end{array}$ & 48 & 64.9 & 15 & 20.3 & 11 & 14.9 & 0 & 0 & 0 & 0 & 4.50 \\
\hline $\begin{array}{l}\text { I will try to learn English as much as possible because I } \\
\text { am interested }\end{array}$ & 32 & 43 & 38 & 51.4 & 4 & 5 & 0 & 0 & 0 & 0 & 4.38 \\
\hline Gran mean & & & & & & & & & & & 4.56 \\
\hline
\end{tabular}

NB: $\mathrm{SA}=$ Strongly Agree, $\mathrm{A}=$ Agree, $\mathrm{UD}=$ Undecided, $\mathrm{D}=$ Disagree, $\mathrm{SD}=$ Strongly Disagree,

As it can be seen from table 12, the trainees response to the statements which express positive attitude towards learning English show their agreement with mean score between 4.72 and 4.38. In other words, the grand mean 4.56 of positively stated statements indicates above the scale given for 'strongly agree'. The mean scores and grand mean of the result imply that trainees have positive attitude towards English language learning. That is, trainees' attitude towards learning the language is good.

\section{DiSCUSSION OF FINDINGS}

The first research question was formulated to elicit the particular English language skills/areas of knowledge trainees need to have. As the questionnaire revealed that even if all English language skills are very important, trainees gave high priority to writing skill. This finding is in line with the finding of Kummar (2020). Next trainees put speaking, reading and listening $2^{\text {nd, }} 3^{\text {rd }}$ and $4^{\text {th }}$ important skills for their academic study. In addition, vocabulary was needed more than grammar. The data obtained from English language and most content area teachers' interview also confirmed the data gained from trainees' questionnaire. While Shibeshi's (2016) study on nursing students found writing skill the first important skill followed by reading skills, Elleni (2010) found listening and speaking skills the most important skills. Habtamu's (2008) study also pointed out that speaking and writing skills were the most important skills for students followed by listening and reading skills. Similarly, Tadele and Haileleul's (2015) study revealed that writing and reading skills were the most important skills for business students in Adama Science and Technology University followed by speaking and listening skills. Therefore the finding of this study was not in line with what has been suggested by Elleni(2010), Shibesi(2016), Tadele and Haileleul(2015) and Habtamu(2008).

Concerning trainees' needs of English language sub-skills, listening to lecturers to take notes and listening to class discussions were given high priority by students. The data obtained from both English language and content area teachers supported trainees' response. The findings of Elleni (2010), Tagele (2007), Belachew (2008), Tadele and Haileleul (2015) and Gashaw (2007) were concurrent with the present study because all the results indicated that listening to lecture to take notes and teachers' instruction were the first important listening activities for trainees'. But Habtamu's (2008) study on Fine Arts students was not concurrent with the present study because his finding portrayed listening at the conference and meeting was one of the most important listening sub-skill for students. The reason for this might be the nature of the course and the teaching system that Fine Arts students use.

Regarding speaking activities, the data obtained from trainees' questionnaire and teachers' interview, asking and answering questions (in classroom, lab and fields), participating in whole class discussion (in classroom, field practice) and presenting assignments and project works in the classroom were highly needed speaking activities. Regarding this Brown (1994) stated that since speaking skill is an interactive process of constructing meaning that involves producing, receiving and processing information, its' sub-skills like asking and answering questions and participating in the class discussion are very important for students' learning success. The finding of Tagele (2007), Elenni (2010) and Gashaw (2007) are concurrent with the present study. But, the findings of Tadele and Haileleul's (2015) as well as Habtamu's (2008) study were not concurrent with the present study.

The questionnaire also revealed that reading different reference books and handouts as well as lecture notes were indicated as more important reading sub-skills for trainees' academic study. Both English language and content area teachers during interview said reading reference books and handouts are the most important reading activity. Generally, this result is similar to Gashaw's (2007), Belachew's (2008) and Tagele's (2007) study. Elenni (2010) also indicated that reading reference books and passages should be relevant to the area of learners because reading generates learners' motivation to read more for their academic achievement.

The data also indicated that writing different project works, sample business and personal letters and lab and field reports were the $1^{\text {st }}, 2^{\text {nd }}$ and $3^{\text {rd }}$ most important writing sub-skills for trainees. Content area teachers' interview results were similar to the data obtained from trainees' questionnaire. For example, English language teacher 2 said trainees need to write different sample personal and business letters, CV and lab \& field reports. But the data gained from the two English language teachers' interview had some disparities with the data obtained from the above respondents. That is, during interview both English language teachers said writing sample business and personal letters including CV formats was the $1^{\text {st }}$ important writing activity for trainees' academic study. The disparity may come from the course which they were teaching. 
The second research question was designed to find out the difficulty level of skills to trainees. Trainees identified speaking skill as the most difficult skill followed by writing, reading and listening skills respectively. The interview questions conducted with English language and content area teachers revealed the same result. For instance, English language teacher 1 reported that speaking and writing skills are more difficult for trainees than non- productive skills. And content area teacher 2 claimed speaking writing, reading and listening skills are relatively difficult activities for trainees in their academic setting.

In line with this finding, there are many research works which showed speaking as very difficult skill for trainees at the university and college levels. For example, Gan (2012), Myles (2009) cited in Chatsgnoen (2015) and Belachew (2008) revealed that speaking skill is a great problem for trainees' academic success. Additionally, Gashaw's (2007) result is in line with the present study. But, Elenni's (2010) study was only partially concurrent to the present study because her study depicted that speaking is the first difficult skill followed by listening, writing and reading skills.

Furthermore, trainees' questionnaire depicted listening to lecturers to take notes (in classroom \& lab), listening the content of in-class activities and listening to instructors' oral presentation were the most difficult listening activities for trainees academic study. In support of this, most of English language and content area teachers' interview results confirmed the finding obtained from trainees' questionnaire. There are studies which have similar result with the present study. For example, Taddele and Hailelul (2015), Belachew (2008), Javis et al. (2020) and Tagele (2007) revealed that listening to lecturers to take note is the most difficult listening activity for trainees'. But Gashaw's (2007) finding is not in line with the finding of this study because his finding revealed that listening to the workshop is the first difficult listening activity for trainees.

Concerning speaking activities, trainees' questionnaire identified presenting assignments and project works, asking and answering question in job related training and making oral conversation with classmates and instructors were identified the most difficult speaking activities. The data obtained from English language and content area teachers' interview assured these difficulties. The result of this study supports the work of Tavil (2010) cited in Chatsgnoen (2015). The finding is also consistent with other similar studies. For example, Gashaw's (2007) and Belachew's (2008) findings are in line with the finding of this study because they stated that students have a great problem to give oral presentation standing in front of their classmates and teachers.

Concerning reading activities, the result obtained from trainees' questionnaire, English language and content area teachers' interviews revealed that reading technical secretarial manuals and reference books as well as guides and reading rules of writing different types of letters were the most difficult reading activities for trainees'. In line with this finding, some researchers have revealed that reading skill, especially reading manuals, handouts and reference books were the most difficult activities for students' academic success. For example, studies show that electricity students have difficulties in reading handouts and reference materials (Tagele, 2007) and Tank Machine Trainees have difficulties in reading different manuals (Gahaw, 2007).

Writing sample job application letters and CVs, expressing ideas appropriately, writing lab and field reports and writing project works as well as term papers were the most difficult writing activities as trainees' questionnaire depicted. The data obtained from some teachers' interview to some extent assured trainees' response. Two content area teachers in their part reported that trainees encountered great difficulties in organizing grammatically correct sentences and writing lab and field reports. From the two English teachers, teacher 1 said expressing ideas in written form and writing different reports by organizing well-constructed paragraph are the most difficult writing activities for trainees' academic study. But teacher 2 said writing different term papers and project works by organizing readable texts is trainees' writing difficulty. This is the only difference on the English teachers' response. Thus, the present study revealed that writing sample job-application letters and CVs, expressing ideas appropriately and writing different projects works, assignments, term papers and class works using grammatical correct sentences are the most difficult activities.

The third research question of this study was formulated to elicit the general attitude of customer contact and secretarial operation coordination trainees. As the trainees' questionnaire indicated, most of trainees had positive attitudes towards learning the English language because the average mean values were above 4.5. Generally, the study depicted that trainees have positive attitude towards learning the English language.

\section{CONCLUSIONS}

According to the findings, the following conclusions were drawn about trainees' English language needs, difficulties, and attitudes towards learning the English language.

- All English language skills are important for trainees' academic success. But to give priority, writing skill was found the $1^{\text {st }}$ highly needed skill followed by speaking, reading and listening skills. This could imply that there is high need for learning the English language skills.

- With regard to the needs of micro-skills, listening to lecturers to take notes (in classroom and lab), listening to class discussions, participating in whole class discussion (in classroom, field practice), reading reference books (English for secretary, customer relationship and effective secretary), reading lecture notes, writing different project works like term papers \& assignments and writing sample personal and business letters are the most important micro-skills trainees need to have for their academic study. Similarly, it was found that the knowledge of vocabulary is more important than grammar. 
- The finding of the study also demonstrated that speaking, writing, reading and listening skills were reported as difficult English language macro-skills according to their order. Specifically, listening to lectures to take notes (in classroom and lab), listening the content of in-class activities, presenting assignments and project works in the class, asking and answering questions orally in job-related trainings, reading technical secretarial manuals and guides and reading rules of writing different types of letters, writing sample job-application letters \& CV, expressing ideas appropriately by using English language and writing different projects works, assignments, term papers and class works were shown as the most difficult activities. In addition to this, there is evidence that the skills seemed to be de-emphasized in their courses.

- Finally, the finding of the study showed that trainees have positive attitude towards learning English language.

\section{RECOMMENDATIONS}

In the view of the findings and their implication, the following recommendations are made.

1. Since there is no specifically designed English language teaching materials, an appropriate English language syllabus should be designed for Customer Contact and Secretarial Operation Coordination TVET trainees by considering trainees' English language needs and difficulties.

2. In order to design appropriate teaching material which is pertinent for trainees academic purpose, syllabus designers ought to consider trainees English language skills and sub-skills.

3. English language skills like Speaking and writing skills including their micro skills should be considered and emphasized during syllabus designing.

4. Since customer contact and secretarial operation trainees have great problem on speaking and writing skills including their respective activities, teachers should encourage trainees to speak and write by providing appropriate tasks and activities in the classroom.

5. With regard to the learning and teaching processes in TVET institutions, English language and content area instructors should give more emphasis to those English language skills.

\section{REFERENCES}

[1] Ahmed A., Brehanu F.and Ayele L. (2017). Investigating the Relevance of ESP for TVET (Technical and Vocational Education Training) college in Ethiopia. International Journal of Multi Disciplinary and current Research. Vol. 5, P 79-87.

[2] Belachew Z. (2008). English Language Needs Analysis of Construction Trainees in Entoto Technical Vocational Education Training (TVET) College. Unpublished MA Thesis: Addis Ababa University.

[3] Biniam T., Adinew T. and Deepika N. (2015). English for University students in Ethiopia: Implications of Needs Analysis at Haramaya University, Ethiopia. American Journal of Educational Research. Vol. 3, No. 1, pp. 86-92.

[4] Chams E. (2016). Introduction to English for Specific Purpose. Tlemcen. Abou Belkaid University press.

[5] Cresswell, J. (2012). Educational Research: Planning, Conducting and Evaluating Qualitative and Quantitative Research (4th ed.). Boston: Pearson Education.

[6] Dudley-Evans, T. and John, M. (1998). Developments in English for Specific Purpose. Cambridge. Cambridge University Press.

[7] Elleni P. (2010). An Assessment of the English Language Needs of Tourist Guide Students and the Language Course Materials at Catering Tourism Training Institute (CTTI) and Lion Ethiopia Tourism and Hotel College (LETHC). Unpublished MA Thesis: Addis Ababa University.

[8] Gashaw S. (2007). English Language Needs Analysis of 10+3 Tank Mechanics Trainees of Major General Mulugeta Bule Technical and Vocational Education Training College. Unpublished MA Thesis: Addis Ababa University.

[9] Habtamu D. (2008). English Language Needs Analysis of Fine Art Students at Mekelle College of Teacher Education. Unpublished MA Thesis: Addis Ababa University.

[10] Hutchinson, T. and Waters, A. (1987). English for Specific Purpose. Cambridge: Cambridge University Press.

[11] Jarvis, A. Kohnke L., \& Guan G. (2020). Academic Listening Strategy Use at an English-Medium University. Asian ESP Journal, Volume 16, Issue 3, pp.8-29.

[12] Kothari, C.R. (2004). Research methodology: Methods and Techniques. Jiapur: India.

[13] Krathwohl, D. R. (1998). Methods of Educational \& Social Science Research: An Integrated Approach. Reading, Massachusetts: Longman.

[14] Kumar T. (2020). Assessing Language Needs and proficiency of English Graduates of Prince Sattam Bin Abdulaziz University for designing pre-placement training and workshops. The Asian ESP Journal, Volume 16, Issue 4, pp.153-168.

[15] Shibeshi A. (2016). Analysis of the English Language Needs of BSc Students: The Case of Higher Education Institutions in Bahir Dar city, Ethiopia. English for Specific Purpose World, Volume 1, Number 50, pp.1-27.

[16] Tadele M. \& Haileleul Z. (2015). English Language Needs Analysis of Business Students at Adama Science and Technology University. Nawa Journal of Language and Communication Volume 9: Number 1. P 150-193

[17] Tagel E. (2007). An Investigation in to English Language Course Needs of Electricity Students of Dilla TVET College. Unpublished MA Thesis: Addis Ababa University.

Sualih Mussa has a Ph.D. in Teaching English as a Foreign Language. He has taught English for over twenty years in high schools and universities. He is now an instructor in Debre Markos University. 
Yitayal Wondie has an M.A. in Teaching English as a Foreign Language. He has taught English for over fifteen years in high schools, colleges and universities. He is now an instructor in Bonga University. 